\title{
EDITORIAL
}

\section{CONFLICT IN SYRIA: FINDING HOPE AMID THE RUINS}

\section{Vincent Bernard, Editor-in-Chief}

Humanity has been undergoing a trial of fire and blood in Syria since 2011. What is happening? Over time, this conflict has exhibited all possible guises of war: civil war, proxy war, siege warfare, cyber-warfare and war against terror. All forms of past and present warfare seem to converge in this one conflict. A war against children, against hospitals, against cities, against first-aid workers, against memory, against justice maybe these are more accurate titles for this war.

Whatever names we give it, we can attempt to grasp the enormity of this tragedy with some figures and orders of magnitude. Although there is no widespread agreement on the number of dead, a New York Times article published in April 2018 puts the most widely accepted death count at 470,000. ${ }^{1}$ According to a UNICEF report, as of March 2018, around 30,000 people were wounded per month, 1.5 million were living with a permanent handicap, 6.5 million were suffering from food shortages, and $70 \%$ of the population was living in extreme poverty. 1.75 million children were not able to attend school, with one out of every three schools unfit for use owing to the war. ${ }^{2}$

More than 11 million people, or around half of the pre-war population, have been uprooted from their homes. Some 5 million people have had to flee the country, and 13.5 million rely on humanitarian assistance to survive. ${ }^{3}$ Most of the country's infrastructure has been destroyed, the economy has collapsed, the country's health-care system - among the best in the region before the war - has imploded, and entire cities and neighbourhoods have been reduced to vast ruins.

But any attempt to estimate the losses in terms of human lives or material damage simply does not convey the suffering that has been inflicted, the physical and psychological trauma that will plague the war's victims and their loved ones for the rest of their lives, or the impact of the violence and physical displacement on future generations.

The shockwaves from the war in Syria are being felt well beyond the country's borders. This is most apparent in the fate of the millions of Syrians who have had to flee the country. Their future is now in the hands of their host countries, which in many cases are deeply divided over the question of asylum. Beyond the community divisions that the war has laid bare, the involvement of both regional and great powers in support of one side or the other has turned the Syrian people into hostages of competing interests that they have nothing to do with. The chaos in Syria has spawned attacks by transnational armed groups acting both within the country's borders and thousands of miles away, wherever 
lone individuals or networks of terrorists strike in their name. What will become of the thousands of foreign fighters who have gone off to join the fight in Syria? What should be done with them and their families when they are captured?

The war in Syria has even helped to revive the spectre of the Cold War: what began as the so-called "Arab spring" popular uprising has evolved into a regional conflict, with several great powers stepping in and providing support to the opposing sides. In another throwback to the Cold War era, multilateral mechanisms designed to restore peace were quickly paralyzed, and as a result the horrors produced by the conflict have exploded since 2011 .

Now that government forces have taken back control of many urban areas, the war seems to be entering a new phase. People who fled the fighting are starting to return home. However, while the period of major siege operations aimed at winning back territory appears to be ending, the conflict drags on. And while the humanitarian needs are changing, they are no less daunting.

Given the scope of the destruction, the significance of this conflict as a new paradigm of war and the utter contempt that has been shown for international humanitarian law (IHL), the Review chose to devote this issue to Syria. What's more, we wanted Syrians to speak for themselves. With this in mind, and with the support of the International Committee of the Red Cross (ICRC) delegation in Damascus, the Review went to Syria in February 2018 - just as the siege of Ghouta was getting under way-in order to meet with researchers, civil society practitioners, legal experts and doctors, along with aid workers from the ICRC and the Syrian Arab Red Crescent (SARC). The articles in this issue, which highlight important insights from a humanitarian, legal, psychological and urban-planning perspective, unexpectedly provide a glimmer of hope for the country's recovery.

\section{Destructive rage}

Day 1: To enter Syria, the ICRC has us transit through Lebanon. From Beirut, we take the road to the Syrian border. In a sad twist of fate, at the border crossing, tourist posters still tout the country's architectural and historical riches: the ancient city of Palmyra, Aleppo's medieval citadel, and Krak des Chevaliers - the largest Crusader castle.

1 Megan Specia, "How Syria's Death Toll Is Lost in the Fog of War", The New York Times, 13 April 2018, available at: www.nytimes.com/2018/04/13/world/middleeast/syria-death-toll.html. The Syrian Observatory for Human Rights, based in the UK, reports a figure of 511,000 people killed between March 2011 and March 2018; see Angus McDowall, "Syrian Observatory Says War Has Killed More Than Half a Million', Reuters, 12 March 2018, available at: www.reuters.com/article/us-mideastcrisis-syria/syrian-observatory-says-war-has-killed-more-than-half-a-million-idUSKCN1GO13M. Other sources provide smaller figures; see, for example: "Monthly Statistical Report on Casualties in Syria March 2018", Violations Documentation Center in Syria, 2018, available at: http://vdc-sy.net/wpcontent/uploads/2018/04/Monthly_Stat_Rep_Mar18_EN.pdf.

2 UNICEF numbers (gathered with WHO and Handicap International) as of March 2018, available at: www.unicef.org/mena/stories/seven-years-war-syria-numbers.

3 See the ICRC's "War in Syria" web page, available at: www.icrc.org/en/where-we-work/middle-east/syria/ war-syria. 
This is my second time in this country. I was lucky enough to visit Syria in the 1990s, invited by a friend who took us to most of these wonderful sites. Although less well-known and less visited than Egypt and Jordan, Syria has an incredibly rich history and contains within its borders several of the world's most important historic sites and a number of gems of both ancient and medieval architecture. While numerous archaeological missions have unearthed, explored and preserved the country's historical ruins, these out-of-the-way sites received few visitors until the end of the twentieth century. This made the experience all the more enchanting: like us, the handful of tourists who strayed from the beaten path to visit these sites could almost feel that they were among the first people to walk these ruins after centuries of neglect. We never imagined that some of these centuries-old treasures would disappear, surviving only in our memories and as faded images on old tourist posters.

The country's tourism industry was just starting to flower when the crisis broke out. The intense bombing, coupled with a destructive rage on the part of the belligerents, has taken a great toll on this heritage of mankind. Sadly, many people only learned of Palmyra - the amazing desert city - when the so-called Islamic State group started destroying its most beautiful monuments.

The destruction of Syria's protected cultural property is now being used for purposes of propaganda and terror, and has become one of the defining features of this conflict. In this issue of the Review, Ross Burns reports on the damage inflicted on Syria's cultural heritage and argues in favour of rebuilding sites that have been laid waste by the war rather than simply reconstructing them in 3D models. Polina Levina Mahnad sets out the legal instruments that protect cultural property as well as several clever, practical measures taken during the conflict to further safeguard them. The measures she describes could serve to improve compliance with the law in other areas as well, apart from cultural property.

\section{Portrait of a disaster}

Day 2: We are now in Syria, and our nerves are immediately assailed by the thunder of bombing, both near and far. From the rooftop we see warplanes above us and, in the distance, large mushrooms of grey smoke whenever a bomb or shell hits a building. Our thoughts soon turn to anguish as our colleagues and new acquaintances share their worries for family members living in dangerous areas and their sense of dread at the prospect of receiving the terrible news of a loved one being seriously wounded.

While the attacks on cultural property were shocking, large parts of the country have in fact been destroyed. The massive and relentless bombing of Syria's cities is another feature of this war. After years of fighting, the scope of destruction is mind-boggling - an impression that ICRC president Peter Maurer shares in his interview for this issue when comparing Syria to the many other war zones that he has visited in recent years. For Mr Maurer, the other striking feature of this conflict is the disregard for the safety of hospitals and medical 
staff. First-aid centres now have to be located underground in order to continue operating and to shield patients from the bombs. These medical shelters are one of the conflict's tell-tale images.

In our 2016 issue on "War in Cities", an Aleppo resident named Yasser gave his account of life in that war-torn place. "We were caught between the two conflicting sides", he said. "We seemed to have been stuck between a rock and hard place as there was no way out. I would not have wanted any human being to go through the kind of hardships that we did." 4 As explained in that issue, including through the accounts of Aleppo residents, the conflicts in Syria and neighbouring Iraq were primarily urban in nature. Urban warfare can cut civilians off from essential services. ${ }^{5}$ Limiting or blocking access to water is one tactic that various parties to the Syrian conflict have employed in an attempt to cause indiscriminate harm to their adversary. ${ }^{6}$

In another sad twist of fate, with Syria's cities reduced to fields of rubble, experts have identified poorly managed urban development and various demographic challenges as two of the underlying causes of the conflict. We met with architect Marwa Al-Sabouni, who survived the protracted battle of Homs along with her family. In her book The Battle for Home, she writes about how the destruction of the traditional urban fabric in Syrian cities created or stoked sectarian and community animosity, which ultimately led to the war. In her article for this issue, she proposes a new approach to urban planning when it comes time to rebuild Syria's cities - one that will promote peaceful coexistence and avoid past errors.

Despite the threat of bombardment, Professor Yassar Abdin made the dangerous journey to meet with the Review team. Abdin, an architect and urban planner, agreed to write a study on the "social insecurity" of Greater Damascus before the war. During our discussion a mortar shell hit the building next door, and we all had to rush to a safe room in the basement.

The destruction of the built environment only hints at the psychological devastation that the people have suffered: for every city or village that has been destroyed, how many bereavements and separations take place, how many people are impoverished, uprooted or humiliated, and how many are traumatized by sexual violence? Professor Mazen Hedar, president of the Syrian Association of Psychiatry, painted a dismal picture of the impact of the war on Syrians' mental health. Working in a country where admitting to psychological disorders was still considered taboo before the war, Dr Hedar discusses remote online consultations with patients - an innovative solution adopted by therapists in response to the

4 "Life in a War-Torn City: Residents of Aleppo Tell Their Stories", International Review of the Red Cross, Vol. 98, No. 901, 2016, p. 17, available at: www.icrc.org/en/international-review/article/life-war-torn-cityresidents-aleppo-tell-their-stories.

5 See, e.g., ICRC, Urban Services During Protracted Armed Conflict: A Call for a Better Approach to Assisting Affected People, October 2015, available at: www.icrc.org/en/publication/4249-urban-services-duringprotracted-armed-conflict.

6 "Red Cross: Water Being Used as Weapon of War in Syria", Al Jazeera, 2 September 2015, available at: www.aljazeera.com/news/2015/09/red-cross-water-weapon-war-syria-150902114347090.html. 
lack of skilled practitioners in the country and the challenge of meeting with patients in person.

\section{Not enough space for humanitarian workers}

Day 3: At the end of a long day at work, Marianne Gasser, the head of the ICRC's delegation in Syria, sits down with us in her office to brief us on her experience. She has spent years working in this country both before and during the war. She speaks of tense negotiations, dangerous forays across front lines, the "successes" and limits of humanitarian work, and the frustrations.

Armed groups have splintered and multiplied, religious and community radicalism - which includes a rejection of any foreign presence - has proliferated, and bombings are either indiscriminate or specifically target medical facilities. How can a humanitarian organization operate in such a dangerous and volatile environment?

The challenges posed by the conflict in Syria are especially complex given its particular features and the growing number of groups engaged in violence. How can you convince the fighters to allow humanitarian organizations through, in order to help civilians caught in the middle? How can you get safety guarantees from increasingly radical and fragmented groups? How can you maintain a neutral, independent and impartial humanitarian space in a conflict where each side demonizes the other? In reality, the conflict is a fight not only for the streets of Syria's cities, but also for people's minds. Each side engages in intense propaganda both inside and outside Syria through social media, online proselytism and fake news, in order to win over adherents.

For humanitarian organizations, the question of access is crucial. In Syria, humanitarian action is further constrained by the inability to operate freely on both sides of the lines of control. The question of humanitarian access was already a concern when the conflict broke out; ${ }^{7}$ since 2012, the Review has published several articles on the rules governing humanitarian access. ${ }^{8}$

7 In 2012, Rony Brauman of Médecins sans Frontières (MSF) admonished the ICRC on these pages for its decision to engage in dialogue with the Syrian government and carry out its humanitarian work in government-controlled zones by crossing lines rather than by working from "liberated zones" (i.e., areas under the control of the government's opponents). He contrasted the ICRC's operational decision with that of MSF, which was working solely in the opposition zones; it reached the zones by crossing borders without requesting the authorities' approval. The situation on the ground then evolved, and radicalized armed groups took control of large zones, rejecting the presence of humanitarian organizations. Rony Brauman, "Médecins sans Frontières and the ICRC: Matters of Principle", International Review of the Red Cross, Vol. 94, No. 888, 2012, available at: www.icrc.org/en/ international-review/article/medecins-sans-frontieres-and-icrc-matters-principle.

8 Emanuela-Chiara Gillard, "The Law Regulating Cross-Border Relief Operations", International Review of the Red Cross, Vol. 95, No. 890, 2013, available at: www.icrc.org/en/international-review/article/lawregulating-cross-border-relief-operations; Françoise Bouchet-Saulnier, "Consent to Humanitarian Access: An Obligation Triggered by Territorial Control, not States' Rights", International Review of the Red Cross, Vol. 96, No. 893, 2014, available at: www.icrc.org/en/international-review/article/consenthumanitarian-access-obligation-triggered-territorial-control. 
The ICRC has been unable to enter all conflict zones but has strived to stay true to its humanitarian principles of neutrality, independence and impartiality. It has also sought to fulfil its role as a neutral intermediary and has supported the relief efforts of the SARC, which the Syrian government chose as the exclusive partner for international aid organizations. In this issue, a series of photos taken by the SARC and the ICRC shows the work being done by the International Red Cross and Red Crescent Movement in the conflict, and the support that the Movement provides to those seeking to rebuild their lives.

Despite these extraordinary difficulties, relief workers in Syria continue to draw on a wellspring of courage and creativity in carrying out their work. Alongside the images of destruction that have come to epitomize this conflict, we will remember the images of courage and solidarity - those showing the perseverance of Syrian and foreign doctors, the first responders pulling victims from the debris, and the courage of the SARC volunteers, sixty-six of whom have been killed while carrying out their duties since the conflict began. ${ }^{9}$

For the ICRC, "[h] umanity cannot be measured in terms of relief provided, but in the real recovery of affected people". ${ }^{10}$ The organization provided food assistance to 3,269,593 beneficiaries in 2017 and, thanks to its efforts, 15 million people country-wide have benefited from a regular supply of water and adequate living conditions. ${ }^{11}$ Aid workers are learning to work in cities, which are not only the site of massive infrastructure damage but are also receiving more and more displaced people. ${ }^{12}$

\section{Ongoing struggle to uphold the law}

Day 4: After a night filled with bombings, a staff member reaches the ICRC delegation in tears: her cousin has just been seriously wounded at home - in a residential neighbourhood far from any military objective - after a shell hit her kitchen window. Debris from the window lodged in her back, potentially paralyzing her for life.

There is a loud explosion nearby. A plume of black smoke rises above the rooftops. A lone rocket, fired at random, has just destroyed a taxi driving down a nearby street, killing the driver. There is no possible military justification for this type of attack.

Some of the most basic tenets of IHL have been violated during the conflict in Syria in the form of attacks on civilians, hospitals and first-aid posts, the use of

9 See ICRC, Annual Report 2017, 13 June 2018, p. 488, available at: www.icrc.org/en/document/annualreport-2017.

10 Peter Maurer, "Humanity not Measured by Relief Items Distributed but by Recovery of People in Need", speech to UN General Assembly High-Level Event on Syria, 26 September 2018, available at: www.icrc. $\mathrm{org} / \mathrm{en} /$ document/humanity-not-measured-relief-items-distributed-recovery-people-need.

11 ICRC, above note 9, pp. 487-492.

12 See ICRC, above note 5; ICRC, Displaced in Cities: Experiencing and Responding to Urban Internal Displacement Outside Camps, 16 August 2018, available at: www.icrc.org/en/publication/4344displaced-cities-experiencing-and-responding-urban-internal-displacement-outside. 
chemical weapons and the torturing of detainees. Of course, most armed conflicts see their share of crimes, and a golden age of full compliance with IHL has never existed. Still, maybe what IHL's defenders are discouraged by is the contrast between the progress achieved in recent decades in the further development and dissemination of IHL and international criminal justice, on the one hand, and the reality on the ground, on the other. Every war crime that goes unpunished represents a failure of IHL and its defenders - and a failure for all of humanity.

The use of chemical weapons during the conflict is one of the most tragic symbols of this contempt for IHL. Yet this violation of one of the most universally accepted rules was met with unanimous condemnation, hoisting the issue of IHL compliance to its rightful place in the discourse surrounding this conflict. In this issue of the Review, Yasmin Naqvi, an international law expert, argues that the special importance placed by the international community on the use of chemical weapons could serve as the basis for creating a Syria tribunal.

Another sign of the importance of IHL compliance can be seen in the efforts of the international community to protect civilians from the effects of hostilities. The idea of creating "safe zones" for civilians was raised more than once. The Astana Memorandum, in May 2017, set up "de-escalation zones" in order to ease the humanitarian plight in Syria. ${ }^{13}$ In November 2017, the ICRC and the Russian International Affairs Council held a conference on these zones in Moscow in order to clarify the respective responsibilities of States and humanitarian organizations towards civilians in the zones. ${ }^{14}$ In this issue, Emanuela-Chiara Gillard presents the IHL rules that apply to these zones and other so-called "safe areas".

Humanitarian norms should not be considered the sole province of the international community - they are also deeply rooted in Islamic tradition. In his article for this issue, Egyptian professor Ahmed Al-Dawoody, who advises the ICRC on questions of Islamic law and jurisprudence, lays out the rules of Islamic law on the use of force and compares them with the rules of IHL.

Despite the numerous and egregious violations taking place, IHL remains the minimum standard against which the seriousness of crimes is measured, and the only bulwark against an even greater surge in violence. It is also fundamental to the ICRC's work. As Peter Maurer notes:

The Geneva Conventions are an important framework to allow us to negotiate access to populations, to engage in a conversation on the conduct of hostilities [and] to negotiate access to detention facilities. ... [I]t's a framework which is

13 "Final De-escalation Zones Agreed on in Astana", Al Jazeera, 15 September 2017, available at: www. aljazeera.com/news/2017/09/final-de-escalation-zones-agreed-astana-170915102811730.html.

14 ICRC, "Moscow Humanitarium: In Dialogue with Russian Officials and Experts on De-escalation Zones in Syria”, 29 November 2017, available at: www.icrc.org/en/document/moscow-humanitarium-dialoguerussian-officials-and-experts-de-escalation-zones-syria. 
an important guidance on how we can engage with states in order to respect those laws, and not only states but also non-state actors. ${ }^{15}$

The catastrophe in Syria can largely be attributed to impunity for IHL violations. It is clear that so much suffering and destruction, so many uprooted lives and demolished buildings, could have been avoided if the parties to the conflict had decided to follow the simple rules of humanity. Syria represents more than a failure to apply IHL. It represents the failure of the mechanisms created to restore long-term peace $-\mathrm{a}$ failure that has nourished a terrible sense of helplessness in the face of a multitude of crimes. It is also clear that, in order to be lasting, peace must be restored through compliance with international rules.

Simply lamenting the fact that the law has been flouted is not enough. A series of straightforward measures, if implemented by the parties to the conflict, could improve the humanitarian situation today and clear the path to peace tomorrow.

- Allow aid workers to reach people caught up in the war.

- Safeguard medical staff and structures.

- Avoid indiscriminate attacks and do not target civilians.

States with influence over the parties to the conflict can also make a difference by linking their support to compliance with the law. The ICRC presented three recommendations for these States at the Second Brussels Conference on Syria, in 2018:

- First, clarify responsibilities. Who is responsible for what, and on whose behalf? Ambiguity increases the risk of IHL violations.

- Second, improve accountability. States should implement clear procedures to collect allegations of violations, and then investigate them.

- Third, States should add safeguards to arms transfers to parties that are involved in committing violations of IHL.

As Dominik Stillhart, the ICRC's director of operations, stated at the conference: "Humanitarians can put a bandage on the patient. But it's only States that can cure that patient." 16

Talking about the catastrophe in Syria leaves a bitter taste: the international conflict resolution system is paralyzed, the humanitarian space is being continually chipped

15 "Peter Maurer: Why the Red Cross Talks to 'Terrorists"”, Al Jazeera, 5 November 2016, available at: www. aljazeera.com/programmes/talktojazeera/2016/11/peter-maurer-red-cross-talks-terrorists-161103155915754. html.

16 ICRC, "Déclaration du CICR à la deuxième Conférence sur la Syrie qui se tient à Bruxelles aujourd'hui", 25 April 2018, available at: www.icrc.org/fr/document/declaration-du-cicr-la-deuxieme-conference-surla-syrie-qui-se-tient-bruxelles-aujourdhui. 
away at, violations of IHL are deliberate and designed to sow terror, and cruel tactics of the past - such as siege and chemical warfare - have made a comeback.

Yet the writers appearing in this issue of the Review, in their analyses of the causes of the conflict, reject that bitterness. They propose practicable solutions to the problems at hand, and they share a passion for Syria and its people. The Review wishes to thank these authors and everyone who provided input for this issue. They show that there is hope amid the ruins. 